Research article / Научная статья

\title{
Top-level diplomacy in the relations between Russia and the UAE
}

\author{
Al-Mahmadava Shahad Rissan Krabuit \\ Peoples' Friendship University of Russia, \\ 6, Miklukho-Maklay str., Moscow, Russian Federation, 117198 \\ shahadrissan@yahoo.com
}

\begin{abstract}
Multi-faceted partnership is developing between Russia and the UAE - in the trade, economic, political, humanitarian spheres, as well as in the field of high technologies. The positions of both countries on pressing international problems are close to each other particularly on security issues, fighting against terrorism, and the conflict settlement in the Middle East. There is a tendency for the establishing of the close bilateral relations in strategically important areas. The historical visit of President Putin to the UAE on October 15, 2019 was a clear proof of the development of friendly relations and close interaction between the two countries.
\end{abstract}

Keywords: Foreign policy, bilateral relations, Russian-Emirati cooperation, diplomacy, official visit

Article history: Received: 22.04.2021. Accepted: 18.07.2021.

For citation: Al-Mahmadava Shahad Rissan Krabuit. Top-level diplomacy in the relations between Russia and the UAE. RUDN Journal of World History. 2021;13(4):446-453. DOI: $10.22363 / 2312-8127-2021-13-4-446-453$

\section{Дипломатия на высшем уровне В отношениях России и ОАЭ}

\author{
Аль-Махмадава Шахад Риссан Крабуит \\ Российский университет дружбы народов, \\ 117198, Россия, г. Москва, ул. Миклухо-Маклая, д. 6 \\ shahadrissan@yahoo.com
}

\begin{abstract}
Аннотация. Между Россией и ОАЭ развивается многоплановое сотрудничество - в торгово-экономической, политической, гуманитарной сферах, а также в области высоких технологий. Позиции двух стран по актуальным международным проблемам близки, в частности, по проблемам безопасности, борьбы с терроризмом, конфликтному урегулированию на Ближнем Востоке. Прослеживается тенденция развития тесных двусторонних
\end{abstract}

(C) Ибрайымов Г.В., 2021

(c) (i) This work is licensed under a Creative Commons Attribution 4.0 International License https://creativecommons.org/licenses/by/4.0/ 
отношений в стратегически важных сферах. Исторический визит президента Путина в ОАЭ 15 октября 2019 г. стал ярким свидетельством развития дружеских отношений и тесного взаимодействия между двумя странами.

Ключевые слова: внешняя политика, двусторонние отношения, российско-эмиратское сотрудничество, дипломатия, официальный визит

История статьи: Поступила в редакцию: 22.04.2021. Принята к публикации: 18.07.2021.

Для цитирования: Al-Mahmadava Shahad Rissan Krabuit. Top-level diplomacy in the relations between Russia and the UAE // Вестник Российского университета дружбы народов. Серия: Всеобщая история. 2021. Т. 13. № 4. С. 446-453. DOI: 10.22363/2312-81272021-13-4-446-453

\section{Introduction}

In December 1971, the UAE became a federation of six emirates - Abu Dhabi, Dubai, Sharjah, Ajman, Umm Al-Quwain, and Fujairah, while the seventh emirate, Ras Al Khaimah, joined the federation in 1972. Since it was united, the UAE has developed rapidly and is now noted for its modern infrastructure, international events and status as a trade and transport hub.

The President of the UAE is His Highness (HH) Sheikh Khalifa bin Zayed Al Nahyan, who is also a Ruler of Abu Dhabi, the capital city. The Ruler of Dubai, HH Sheikh Mohammed bin Rashid Al Maktoum holds the posts of the VicePresident, Prime Minister and Defence Minister. The Crown Prince of Abu Dhabi and the Deputy Supreme Commander of the UAE armed forces is HH Sheikh Mohammed bin Zayed Al Nahyan.

The UAE is a member of the Gulf Cooperation Council (GCC), the Arab League, the Organization of Islamic Cooperation, the United Nations, the Organization of the Petroleum Exporting Countries, the Non-Aligned Movement and the World Trade Organization. The International Renewable Energy Agency, established in 2009, has its headquarters in Abu Dhabi [1].

The UAE is the Middle East's second largest economy, after Saudi Arabia, and one of the wealthiest countries in the region on a per capita income. Its GDP in 2020 was estimated at 373.15 billion U.S. dollars for 2021, a real GDP growth rate of around 3.3 percent [2]. The UAE owns $5.9 \%$ of the world's oil reserves and the eighth largest proven natural gas reserves. Petroleum exports were US dollars 145.7 billion in 2020. In the medium term, oil and gas (which account for over $70 \%$ of exports and the bulk of government revenue) will continue to underpin the UAE's economy.

However, significant steps towards economic diversification have already been taken, with approximately $65 \%$ of GDP now generated by sectors other than oil and gas. The UAE is also developing a civil nuclear energy program and plans to build four nuclear power reactors. The first, the Barakah nuclear power plant, has already started working. Renewable energy generation is also a focus for the UAE, both for domestic energy needs and in terms of investment abroad. 
The relationship between the Russian Federation and the United Arab Emirates stretches back to December 1971, when the Soviet Union and UAE established diplomatic relations. The relations between two countries have been described as strong and a "strategic partnership" [3].

The United Arab Emirates and the Russian Federation have forged a decadeslong partnership based on mutual respect and definite objectives, leading to various successful outcomes. The UAE-Russia ties stretch back 50 years, with the former Soviet Union (USSR). The USSR established its embassy in Abu Dhabi in 1986, with the UAE following shortly afterwards, opening its embassy in Moscow in 1987. The UAE recognized the Russian Federation as the successor state of the USSR in December 1991. Characterised by high-level diplomacy and dialogue exchange, the UAE and Russia have continued to strengthen their diplomatic ties via numerous mutual visits by delegations from both countries [3].

President Vladimir Putin visited the United Arab Emirates on October 15 2019 with a delegation of Russian ministers, trade representatives, and officials. Putin's trip to the Emirates (his first since 2007) was important for rapidly expanding Russian-UAE ties, which have grown in many areas such as investment, trade, culture, outer space, tourism, and security, in recent years [4]. Strategic partnership that the two countries signed in June 2018 [5] to cooperate in various sectors such as politics, security, economy and culture, along with cooperation in the humanitarian, scientific, technological and tourist domains was a watershed in bilateral affairs, underscoring the extent to which both Moscow and Abu Dhabi value their deepening relationship. Now the two countries are taking this partnership to new heights. While the Russian President and his delegation were in the Emirati capital, he held talks with the UAE's de facto ruler and Crown Prince of Abu Dhabi, Mohammed bin Zayed, who met Putin at the airport upon his arrival from Saudi Arabia. While speaking to Emirati officials Putin gave them his word that they "will not be disappointed" with the more than US dollars 1.3 billion in Russian-UAE investment deals signed during his visit (partnership to cooperate in politics, security, economy and culture) [5]. For Russia, no Gulf Cooperation Council (GCC) member-state is as important in terms of trade. As Putin explained to the UAE's state-owned media: "Of all the Gulf countries, we [Russia and the UAE] have the highest level of trade, US dollars 1.6 billion, but of course, this is not enough. We are all well aware of that and we are working with the UAE's sovereign wealth fund [Mubadala] where the joint platform is valued at nearly US dollars 7 billion [6]."

Indeed, Russia and the UAE have a vibrant and long-standing economic relationships. The partners have also built a robust partnership. Russian exports to the Emirates are mainly commodities, such as precious metals and stones, steel, as well as ferrous metal products, machinery, equipment, vehicles, chemicals, food, wood, paper, and cardboard. Since the mid-2000s, Russian state-owned giants and private firms have done business in the Emirates and compete for some of the country's project tenders. For Russia the UAE. represents an attractive business hub for Africa, Asia, Europe, and the Middle East. Meanwhile, the Gulf state has invested in Russia's gas, oil, real estate, infrastructure and logistics sectors, and seeks to boost its presence 
in Russia's food production sector. Additionally, the two countries share natural resource extraction and are establishing diamond trade centers.

Like virtually all other Arab capitals, Abu Dhabi views Russia's role in the Middle East security architecture as increasingly important. Common concerns and overlapping interests are leading to growing alignment between the Russians and Emiratis. Two conflicts in the region that have drawn Moscow and Abu Dhabi closer are Yemen and Syria. "Al-Bayan" published a very important and positive article appreciated Russian President Vladimir Putin " historical " visit [7]. "Al-Bayan" said: "A milestone for UAE-Russia relations, Vladimir Putin's official visit is the first of its kind by a Russian president since relations between the two countries were established in 1986". Putin's historic visit to the UAE is also part of Russia's stated intention of bolstering ties with Arab and Muslim countries.

Putin's chief foreign policy aide Sergei Prikhodko told reporters that negotiations with the UAE leadership would focus on Middle East peace, Iran's atomic ambitions and sectarian violence in Iraq, according to Reuters [8]. Prikhodko said Russia would use the visit to promote the idea of holding an international conference on the Israeli-Palestinian conflict involving all regional players. The visit also comes amid growth in tourism and trade ties. A Russian diplomat in Abu Dhabi Sergei Kuznetsov told Gulf News that bilateral trade is expected to reach a record $\$ 800$ million (about Dh2.9 billion) in 2019 [4].

UAE Minister of Foreign Affairs Sheikh Abdullah highlighted the rapid growth in bilateral relations in the space sector. "I would like to extend our thanks and appreciation to the Russian minister and the Russian firms, especially the Russian space agency Roscosmos, for advancing our space partnership which culminated in the first space mission and the launch of the first Emirati astronaut into the International Space Station (ISS) in 2019. We are all proud of Hazzaa Al Mansoori and happy that these moments will live forever in the memory of the Emirati people, especially the youth," he said [9].

Hazzaa's eight-day space mission aboard a Russian spaceship to the ISS has a far-reaching impact on the scientific and knowledge aspects in the UAE and encourage many Emirati and Arab youth to venture into the journey of research, knowledge and adventure. The UAE and Russia have over recent years cooperated to maintain the balance in the world oil markets and "tackle imbalances in supply and demand fluctuations" to ensure stability. "The UAE is looking forward to consolidating this partnership with your country in sectors of energy, oil and renewable energy, which constitute the sustainable source of energy for future generations", the UAE Foreign Minister told the Russian minister [10].

The UAE Ministry of Industry and Advanced Technology has reported more than 2,900 Russian companies registered in the UAE, with some 20 Russian commercial agencies. 507 trademarks are also registered in the country bringing inward FDI stocks to US\$940 million (AED3.7 billion) in 2016 [10].

In 1994, the two countries established the Intergovernmental UAE-Russia Commission for Trade, Economic and Technical Cooperation. Since its establishment, the Commission has held many meetings, with a joint working group being established in 2014 to monitor the implementation of the Commission's 
decisions. According to the Russian Ministry of Foreign Affairs, the Russian Fund for Direct Investment (RFDI) and the UAE's Mubadala Investment Company created a platform in 2013 for joint investment in Russia-based projects with a targeted amount of investment partnership worth up to US\$7 billion (AED25.7 billion). In 2016, the RFDI and Mubadala also looked into investing US\$ 300 million (AED1.1 billion) in Russian agricultural firms EFKO Group and AFG National as part of expansion of trade incommodities. In the same year, the RFDI and DP World announced a joint venture to invest around US\$2 billion (AED7.3 billion) in seaports, transport and logistical terminals in various regions across Russia. Abu Dhabi's Mubadala also acquired a $44 \%$ stake worth at least US\$271 million (AED995 million) in an oil subsidiary of Russian company Gazprom [10].

The International Defence Conference (IDEX) and Naval Defense Exhibition and Conference (NAVDEX) 2017 saw a whopping Dh6.9billion worth military procurement deals between the UAE and other international entities. It included a contract between the UAE and Russia for anti-armor missiles, which amounted to over Dh2.6 billion [11]. The contract includes 5,000 anti-armor missiles, as well as training and support with Rosoboron export, said Brigadier General Rashid Mohammed Al Shamsi, official spokesperson for the 13th edition of Idex during a press hearing [12].

Other contracts made between the UAE and foreign countries included Dh611million with Raytheon Company, a major US defense contractor; Dh865million with Swedish Aerospace company and Dh151million with German automotive parts supplier and military technology company, Rheinmetall Group.

ADNOC officials held talks with Russian counterparts discussing joint investment opportunities with Russia in a bid to further expand strategic partnership in the production of hydrocarbons and liquified natural gas (LNG).

Emirates Nuclear Energy Corporation (ENEC) has renewed its 2017 Memorandum of Understanding on cooperation in the field of peaceful uses of nuclear energy with Russian state nuclear corporation Rosatom [13]. The document was signed by Mohamed Al Hammadi, CEO of ENEC, and Alexey Likhachov, Rosatom director general, in Abu Dhabi during Russian President Vladimir Putin's official visit to the United Arab Emirates.

Media cooperation between the two countries is extensive. Various Russian media outlets have set up offices in the UAE, including RIA Novosti and Russia Today. The Emirates News Agency, WAM, also signed Memoranda of Understanding with Russian media outlets Sputnik and RT, in 2018 and 2019 respectively, in a bid to facilitate information, news and broadcast content exchange [14].

The UAE and Russia continue to expand their cultural and tourism links, promoted by the visa exemptions initiated by the UAE in 2017, leading to an increase of Russian tourists into the UAE from 600,000 in the 2015-2016 period to around 1.2 million visited the country in 2018 [15]. Also, around 41,000 Russians are residing in the UAE (the number of the Russian residents in 2018 was 7,280. Meanwhile, the proportion of Russian residents increased during 2019 and 2020 by 14,558 residents.)

Russian pavilion at Expo 2020 Dubai is ready to open its door for visitors in 2021 under the name "Creative Mind: Driving the Future". Russian creativity is unique. Russia has always been an amazing source of great, creative minds. 
The UAE and Russia are bonded by religion and culture. For example, the 20,000 capacity Russian Orthodox Church built in Sharjah illustrates the Russians' and Emiratis' mutual respect for the others' religious roots. To that point, there is a view in the UAE-held by Abu Dhabi's former ambassador to Moscow, Omar Ghobash, that Russia is a great Christian civilization. The international conference on Sunni Islam in Grozny 2016 was an important event in terms of Emirati and Russian efforts to provide visions for the future of Islam based on the rejection of interpretations of the faith considered by both governments to be extremist amid an "intra-Sunni geopolitical rivalry," as Kristin Smith Diwan identified it in her analyses on Foreign Affairs.

Cultural exchange is inherent in the UAE's message of tolerance and coexistence. The country has hosted many Russian cultural events and performances; such activities include the 'Peace International Youth Orchestra' by Russian conductor Valery Gergiev, played in the UAE capital in January 2011. In September 2016, Russia's Krasnoyarsk Opera and Ballet Theatre were on tour in the UAE, where it performed on the Dubai Opera stage. H.H. Dr. Sheikh Sultan bin Muhammad Al Qasimi, Supreme Council Member and Ruler of Sharjah, attended the 32nd Moscow International Book Fair 2019.

\section{Conclusion}

Emirati-Russian exchanges in arts, music, and dance have also emerged as increasingly important aspects of bilateral affairs. Theodore Karasik recently wrote that "some of Russia's finest art and musical traditions are now part of the UAE's art scene," adding that "the momentum of the corridor between Russia and the UAE represents a bridge between two civilizations and establishes a new model for Russian-Middle Eastern relations [16]."

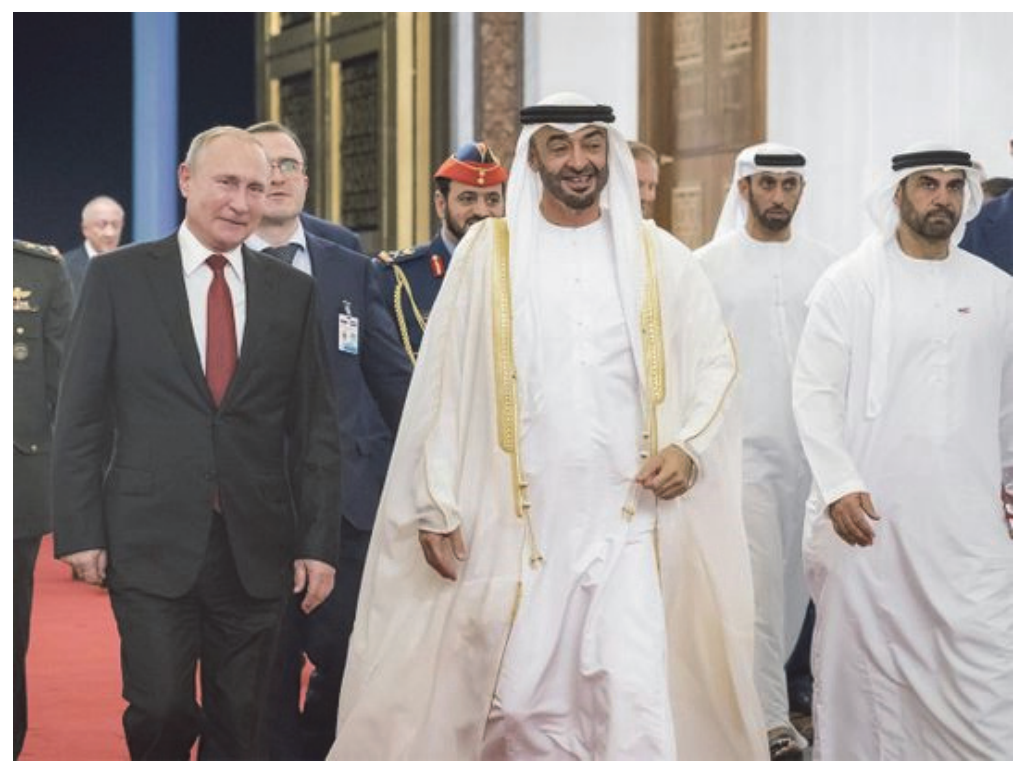

Fig. 1. President Putin and Sheikh Mohamed bin Zayed Crown Prince of Abu Dhabi

Рис. 1. Президент В.В. Путин и наследный принц Абу-Даби Шейх Мухаммад ибн Заид 


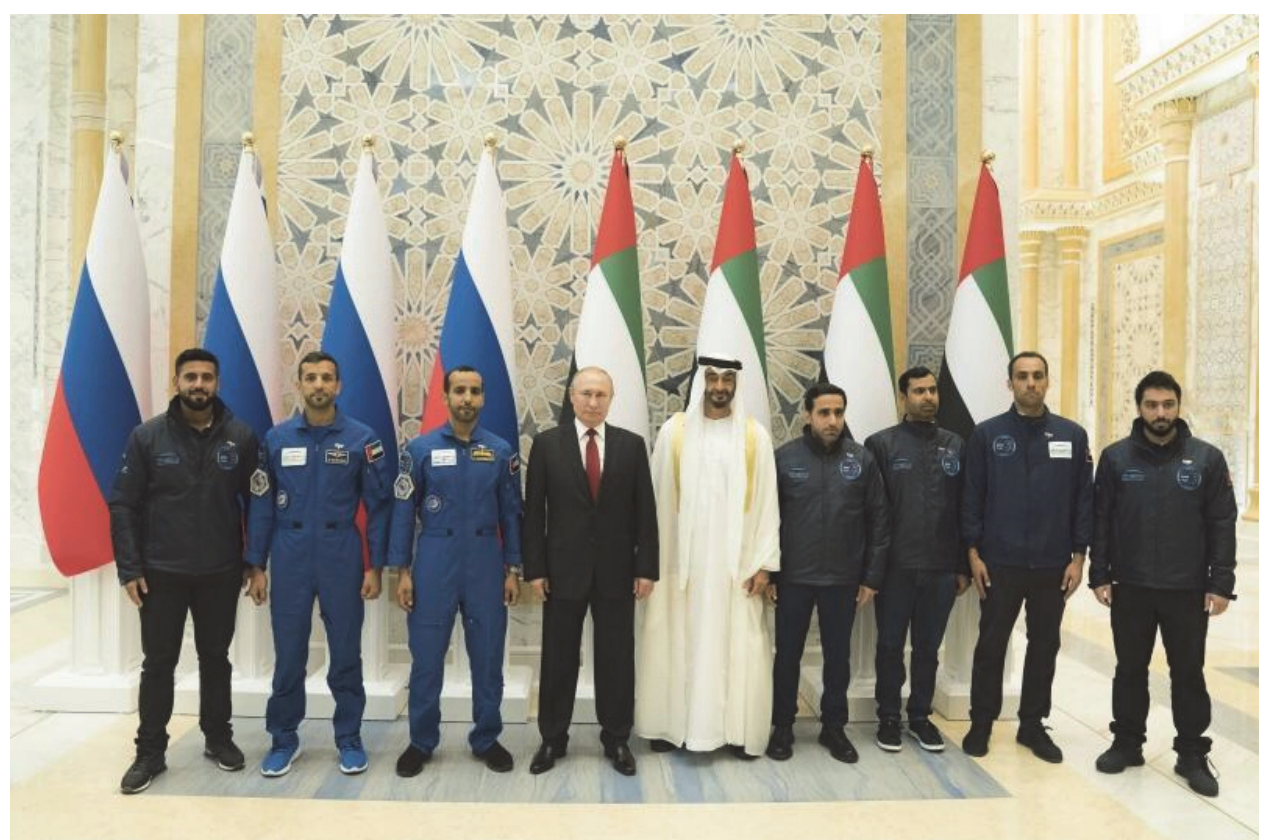

Fig. 2. President Putin and Sheikh Mohamed bin Zayed with the Emirati astronaut Hazaa Al Mansoori

Рис. 2. Президент В.В. Путин и Шейх Мухаммад ибн Заид с астронавтом из ОАЭ Хаззаа Аль-Мансури

\section{References}

[1] UAE Ministry of Interior. Available from: https://www.moi.gov.ae NewsMinistry of Interior MOI - Under the patronage oh Mohammed bin Zayed [Accessed 17.01.2021]. (In Arab.).

[2] Ministry of Energy and Infrastructure in UAE. Available from: https://www.MOEI.ae/ en/home.aspx [Accessed 17.01.2021]. (In Arab.).

[3] Ministry of Foreign Affairs and International Cooperation. Available from: https://www.mofaic.gov.ae/en/mediahub/news/2021/3/9/09-03-2021-uae-minister [Accessed 18.01.2021]. (In Arab.).

[4] Gulf News. Available from: https://gulfnews.com/amp/business/energy/uae-russia-tostrengthen-cooperation-in-oil-nuclear-energy-1.67123891 [Accessed 23.01.2021].

[5] UAE Ministry of Finance. Available from: https://www.mof.gov.ae/en/About/strategy/ Pages/strategy2021.aspx [Accessed 07.02.2021]. (In Arab.).

[6] Emaratalyoum. Available from: https://www.emaratalyoum.com/online/follow-ups/ 2019-10-15-1.1262456?ot=ot.AMPPageLayout [Accessed 07.02.2021]. (In Arab.).

[7] Al-Bayan. Available from: https://www.albayan.ae/across-the-uae/news-and-reports/ 2019-10-15-1.3674868?ot=ot.AMPPageLayout UAE, Dubai, 17 October 2019 [Accessed 16.02.2021].

[8] Putin's historic visit. Reuters. Available from: https:/www.reuters.com/2019/10/15/ putin-in-abu-dhabi-and-mohammed-bin-zayed-describe-the-visit-as-historic. 2019 [Accessed 16.02.2021].

[9] The National News. Available from: https://amp.thenationalnews.com/uae/science/ sheikh-zayed-s-space-ambition-achieved-says-emirati-astronaut-hazza-al-mansouri1.919181 [Accessed 05.03.2021]. 
[10] Mubadala Investment Company. Available from: https://www.mubadala.com/ [Accessed 10.03.2021].

[11] "Deloitte". Available from: https://www2.deloitte.com/content/dam/Deloitte/xe/ Documents/About-Deloitte/mepovdocuments/mepov12/dtme mepov12_whogoesthere.pdf [Accessed 12.03.2021].

[12] Sky News Arabia. Available from: https://www.skynewsarabia.com/ [Accessed 12.03.2021]. (In Arab.).

[13] S\&P Global. Available from: https://www.spglobal.com/platts/en/market-insights/ latest-news/oil/101519-russia-uae-sign-new-energy-cooperation-agreements [Accessed 14.03.2021].

[14] World Nuclear News. Available from: https://world-nuclear-news.org/Articles/Russia,UAE-extend-MoU-on-cooperation [Accessed 14.03.2021].

[15] Business Live Middle East. Available from: https://www.businessliveme.com/ economy/tourism-news/rise-of-russian-tourists-in-uae-dubai-welcomes-8-36-mn-visitorsin-6-months/amp/ [Accessed 14.03.2021].

[16] Theodore Karasik a former Advisor and Director of Research for a number of UAE institutions. Available from: https://www.businessliveme.com/economy/tourism-news/ rise-of-russian-tourists-in-uae-dubai-welcomes-8-36-mn-visitors-in-6-months/amp/ [Accessed 14.03.2021].

\section{Информация об авторе:}

Аль-Махмадава Шахад Риссан Крабуит - аспирант кафедры теории и истории международных отношений, Росийский университет дружбы народов, г. Москва, e-mail: shahadrissan@yahoo.com

\section{Information about the author:}

Al-Mahmadava Shahad Rissan Krabuit - postgraduate student of the Department of Theory and History of International Relations, Peoples' Friendship University of Russia, Moscow, e-mail: shahadrissan@yahoo.com 